\title{
PENGARUH MOTIVASI KERJA DAN KOMPETENSI KERJA TERHADAP KINERJA PEGAWAI DINAS KEBUDAYAAN KOTA MEDAN
}

\author{
BENA BR GINTING \\ Prgram Studi Manajemen Informatika \\ Akademi Informatika dan Komputer Medicom \\ benagintingmunte@gmail.com
}

\begin{abstract}
This research was conducted to find out how Work Motivation and Work Competence Toward Performance of Medan City Culture Department Employees. This study uses three variables consisting of Performance variables namely Employees (Y), while the independent variables are Work Motivation (X1) and Work Competence (X2). This type of research is explanatory research through associative research, namely research that aims to explain the difference between two or more variables. The population in this study were all employees of the Medan City Culture Office received 38 civil servants. The method of data collection is done by literature study questionnaire, and observation. Data analysis conducted in this study was hypothesis testing with t test (partial test) and F test (simultaneous test). The results showed that: (1) based on partial tests of Motivation Influenced the performance of Medan City Culture Department employees with a t test of 3.721. (2) Based on a partial competency test on the performance of Medan City Culture Department employees with a $t$ test of 4.073. (3) Based on the Simultaneous test the Effect of Work Motivation and Work Competence on the Performance of Medan City Culture Office Employees with an F test of 62.332.
\end{abstract}

Keywords: Work Motivation, Work Competence and Employee Performance

\section{PENDAHULUAN}

\section{Latar Belakang Masalah}

Pegawai Negeri Sipil yang bekerja pada instansi pemerintah atau disebut Pegawai Negeri Sipil atau Aparatur Sipil Negara memiliki kontribusi yang besar dalam memajukan instansi pemerintah. Setiap kinerja Pegawai Negeri Sipil memiliki pengaruh yang besar dalam pelaksanaan tugastugas yang diberikan untuk mencapai tujuan instansi pemerintah. Kinerja Pegawai Negeri Sipil pada dasarnya adalah apa yang dilakukan pegawai tersebut sehingga mempengaruhi seberapa banyak mereka berkontribusi kepada instansi pemerintah demi tercapainya visi dan misi instansi tersebut.

Pegawai Negeri Sipil (PNS) sebagai aparatur negara, sebagai abdi negara dan abdi masyarakat, mempunyai posisi sangat strategis dan peranan penting dalam menyelenggarakan pemerintahan dan pembangunan demi kemajuan suatu negara. Sebagai aparatur negara, PNS berkewajiban menyelenggarakan tugas pemerintahan dan pembangunan dengan penuh tanggung jawab, kesetiaan dan ketaatan kepada Pancasila, Undang-undang Dasar 1945, negara dan pemerintah.

Dalam usaha meningkatkan kinerja aparaturnya, pemerintah menetapkan program manajemen kepegawaian berbasis kinerja.
Salah satu peraturan yang dikeluarkan pemerintah untuk tujuan tersebut adalah Peraturan Menteri Pendayagunaan Aparatur Negara Nomor: PER/09/M.PAN/5/2007 tentang Pedoman Umum Penetapan Indikator Kinerja Utama di Lingkungan Instansi Pemerintah.

Kinerja instansi pemerintah merupakan sejauh mana tingkat pencapaian tujuan instansi pemerintah sesuai dengan penjabaran dari visi, misi dan rencana strategi instansi pemerintah.

Kinerja yang baik harus didukung dengan kemampuan dan motivasi kerja. Seperti yang disampaikan oleh Keith Davis (dalam Mangkunegara, 2005:13), ada dua faktor utama yang mempengaruhi kinerja individu yakni kemampuan (ability), dan motivasi kerja (motivation) individu tersebut. Kemampuan individual tergantung dari tingkat pengetahuan (knowledge) yang dimiliki, latar belakang pendidikan, dan keterampilan (skill) yang dikuasai. Sedangkan motivasi kerja individual tergantung sikap (attitude) sebagai motivasi dasar dan lingkungan yang mempengaruhi motivasi tersebut.

Pembinaan dan peningkatan kinerja individu dapat dilakukan dengan pembinaan dan peningkatan kemampuan kerja dan 
motivasi kerja yang dimiliki pegawai. Peningkatan kemampuan kerja dapat dilakukan dengan upaya meningkatkan pengetahuan dan keterampilan kerja pegawai serta peningkatan motivasi kerja dilakukan dengan cara memberikan dorongan kerja, membina sikap mental pegawai, menumbuhkan sikap mencintai pekerjaan dan memberikan kepuasan dalam hal imbalan kerja.

Motivasi adalah alasan atau dorongan yang ada di dalam diri pegawai yang menyebabkan pegawai melakukan sesuatu dengan segenap hati. Motivasi pegawai dapat dipengaruhi oleh gaji yang diterima, kebutuhan akan rasa aman, hubungan antar personal dan kesempatan untuk bekerja.

Dengan adanya motivasi atau dorongan dari dalam diri pegawai dapat merangsang pegawai untuk lebih memberikan tenaga dan pikiran dalam merealisasikan tujuan suatu instansi.

Berdasarkan observasi pada pra penelitian yang telah dilaksanakan di Dinas Kebudayaan Kota Medan, bahwa kinerja pegawai Dinas Kebudayaan Kota Medan belum maksimal, hal ini terlihat dari banyaknya pegawai yang belum memahami tugas dan tanggung jawab yang diberikan. Sehingga hal tersebut akan berdampak terhadap tanggung jawab pegawai dalam melaksanakan pekerjaan yang telah dibebankan kepada masing-masing pegawai. Dan terkadang masih ada pegawai yang mengobrol pada saat jam kerja tentunya hal ini dapat menggangu kinerja pegawai Dinas Kebudayaan Kota Medan.

Setiap instansi tentunya berupaya untuk mendapatkan pegawai yang memiliki kompetensi dan motivasi kerja yang maksimal sehingga dapat memberikan prestasi kerja terhadap instansi tersebut, karena dengan adanya kompetensi kerja dan motivasi kerja yang tinggi dari pegawai sehingga dapat mewujudkan tujuan yang telah ditetapkan sebelumnya.

Berdasarkan keadaan tersebut dan melihat begitu pentingnya kinerja Pegawai yang dipengaruhi oleh Motivasi dan Kompetensi Kerja maka penulis tertarik untuk melakukan penelitian pada tentang "Pengaruh Motivasi Kerja dan

\section{Kompetensi Kerja Terhadap Kinerja} Pegawai Dinas Kebudayaan Kota Medan”.

\section{Batasan Masalah}

Berdasarkan fakta lapangan yang diperoleh, maka batasan masalah dalam penelitian ini adalah Menganalisi pengaruh Motivasi Kerja dan Kompetensi Kerja terhadap Kinerja Pegawai Dinas Kebudayaan Kota Medan.

\section{Rumusan Masalah}

Berdasarkan latar belakang masalah diatas, maka yang menjadi rumusan masalah penelitan dalam penelitaian ini adalah :
a. Apakah Motivasi Kerja dapat mempengaruhi Kinerja pegawai Dinas Kebudayaan Kota Medan?

b. Apakah Kompetensi Kerja dapat mempengaruhi Kinerja pegawai Dinas Kebudayaan Kota Medan?

c. Apakah Motivasi Kerja dan Kompetensi Kerja dapat mempengaruhi Kinerja pegawai Dinas Kebudayaan Kota Medan ?

\section{Tujuan Penelitian}

Adapun yang menjadi tujuan dari penelitian ini adalah sebagai berikut :

a. Untuk mengetahui dan menganalisis pengaruh Motivasi Kerja terhadap Kinerja pegawai Dinas Kebudayaan Kota Medan.

b. Untuk mengetahui dan menganalisis pengaruh Kompetensi Kerja terhadap Kinerja pegawai Dinas Kebudayaan Kota Medan.

c. Untuk mengetahui dan menganalisis pengaruh Motivasi Kerja dan Kompetensi kerja terhadap Kinerja pegawai Dinas Kebudayaan Kota Medan

\section{TINJAUAN PUSTAKA \\ Kinerja Pegawai}

Menurut Benardin dan Russel dalam Priansa (2014:270) menyatakan bahwa, "Kinerja merupakan hasil yang diproduksi oleh fungsi pekerjaan tertentu atau kegiatan - kegiatan pada pekerjaan tertentu selama periode waktu tertentu. Hasil kerja tersebut merupakan hasil dari kemampuan, keahlian, dan keinginan yang dicapai." 


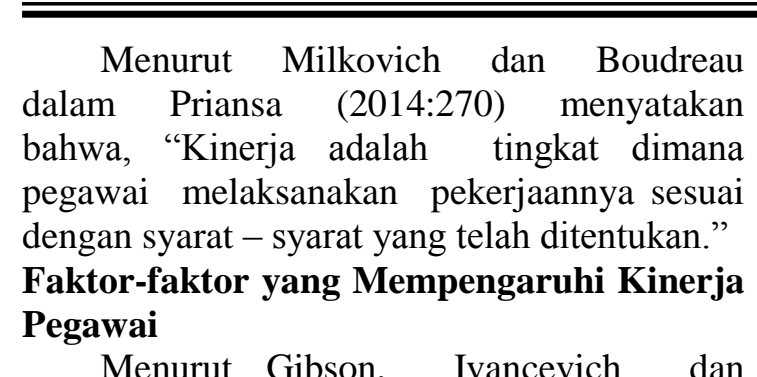
Donnely dalam Priansa (2014:270) menyatakan bahwa, "Faktor - faktor yang mempengaruhi kinerja pegawai adalah variabel individu, variabel psikologis, maupun variabel organisasi.

1) Variabel individu meliputi:
a) Kemampuan dan keterampilan baik fisik maupun mental
b) Latar belakang seperti keluarga, tingkat sosial dan pengalaman
c) Demografi menyangkut umur, asal - usul dan jenis kelamin

2) Variabel psikologis meliputi:
a) Persepsi
b) Sikap
c) Kepribadian
d) Belajar
e) Motivasi

3) Variabel organisasi meliputi:
a) Sumber daya
b) Kepemimpinan
c) Imbalan
d) Struktur
e) Desain pekerjaan

Menurut Simamora yang dikutip oleh Mangkunegara $\quad$ (2014:14), kinerja (performance) dipengaruhi oleh tiga faktor, yaitu:

1) Faktor individual yang terdiri dari:
a) Kemampuan dan keahlian
b) Latar belakang
c) Demografi

2) Faktor psikologis yang terdiri dari:
a) Persepsi
b) Attitude
c) Personality
d) Pembelajaran
e) Motivasi

3) Faktor organisasi yang terdiri dari :
a) Sumber daya
b) Kepemimpinan
c) Penghargaan
d) Struktur
e) Job Design

\section{Teori Motivasi}

Menurut Moekijat (2012 : 45 ), bahwa kata motivasi kata dasarnya adalah motif yang berarti dorongan, sebab atau alasan seseorang melakukan sesuatu. Dengan demikian motivasi berarti suatu kondisi yang mendorong atau menjadikan sebab seseorang melakukan seuatu perbuatan/ kegiatan, yang berlagnsung secara sadar.

$\begin{array}{lrr}\text { Mangkunegara } & (2011 & : 34) \text {, } \\ \text { mengemukakan bahwa motivasi itu } \\ \text { didefenisikan sebagai suatu kecenderungan }\end{array}$ untuk beraktivitas, mulai dari dorongan dalam diri dan diakhiri dengan penyesuaian diri. Stanton mendefenisikan motivasi suatu motif adalah kebutuhan yang distimulasi yang berorientasi kepada tujuan individu dalam mencapai rasa puas.

Mangkunegara (2011:39), mengatakan bahwa motivasi terbentuk dari sikap seorang pegawai dalam menghadapi situasi kerja. Motivasi merupakan kondisi yang menggerakkan diri pegawai yang terarah untuk mencapai tujuan organisasi.

\section{Indikator Motivasi kerja}

Menurut Uno (2009: 73) dimensi dan indikator motivasi kerja dapat dikelompokan sebagai berikut:

a. Motivasi internal

1) Tanggung jawab dalam melaksanakan tugas

2) Melaksanakan tugas dengan target yang jelas

3) Memiliki tujuan yang jelas dan menantang

4) Ada umpan balik atas hasil pekerjaannya.

5) Memiliki rasa senang dalam bekerja.

6) Selalu berusaha mengungguli orang lain.

7) Diutamakan prestasi dari apa yang dikerjakannya.

b. Motivasi eksternal

1) Selalu berusaha memenuhi kebutuhan hidup dan kebutuhan kerjanya.

2) Senang memperoleh pujian dari apa yang dikerjakannya.

3) Bekerja dengan ingin memperoleh insentif.

4) Bekerja dengan harapan ingin memperoleh perhatian dari teman dan 
atasan.

\section{Kompetensi Kerja}

Wibowo (2014:271) kompetensi adalah suatu kemampuan untuk melaksanakan atau melakukan suatu pekerjaan atau tugas yang dilandasi atas keterampilan dan pengetahuan serta didukung oleh sikap kerja yang dituntut oleh pekerjaan tersebut. Kompetensi juga menunjukkan karakteristik pengetahuan dan keterampilan yang dimiliki atau dibutuhkan oleh setiap individu yang memampukan mereka untuk melakukan tugas dan tanggung jawab mereka secara efektif dan meningkatkan standar kualitas profesional dalam pekerjaan mereka.

Kompetensi berdasarkan Peraturan Pemerintah Nomor 100 Tahun 2000, adalah kemampuan dan karakteristik yang dimiliki oleh seorang PNS berupa pengetahuan, keterampilan dan atau sikap perilaku yang diperlukan dalam pelaksanaan tugas jabatannya.

\section{Indikator Kompetensi Kerja}

Zwell dalam Wibowo, (2007:93) memberikan lima kategori kompetensi, yang terdiri dari task achievement, relationship, personal attribute, managerial, dan leadership.

\section{Kerangka Berpikir}

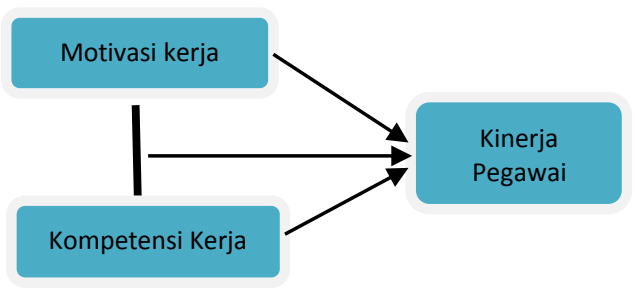

Gambar 1 : Kerangka Berpikir

\section{Hipotesis}

1. Motivasi Kerja berpengaruh positif dan signifikan terhadap kinerja Pegawai Dinas Kebudayaan Kota Medan.

2. Kompetensi Kerja berpengaruh positif dan signifikan terhadap kinerja Pegawai Dinas Kebudayaan Kota Medan.
3. Motivasi Kerja dan Kompetensi Kerja berpengaruh positif dan signifikan terhadap kinerja Pegawai Dinas Kebudayaan Kota Medan.

\section{METODE PENELITIAN \\ Tempat Penelitian}

Penelitian ini dilaksanakan di kantor Dinas Kebudayaan Kota Medan.

\section{Metode Penelitian}

Menurut Manullang dan Pakpahan ( 2014:9) mendefinisikan metode penelitian adalah proses menemukan solusi masalah setelaah melakukan studi yang mendalam dan menganalisis faktor situasi.

Metode yang digunakan dalam penelitian ini adalah metode penelitian survei dengan teknik analisis statistik inferensial. Metode ini dapat memberikan gambaran tentang variabel yang ditemukan, sekaligus menyelidiki pengaruh antara variabel. Karena itu, metode ini mengungkapkan data faktual berdasarkan informasi yang ditemukan.

\section{Populasi dan Sampel Populasi}

Populasi satu kelompok dari elemen penelitian, dimana elemen adalah unit terkecil yang merupakan sumber data yang diperlukan. Manullang dan Pakpahan ( 2014:70).

Populasi adalah wilayah generalisasi yang terdiri atas objek atau subjek yang mempunyai kualitas dan karekteristiktertentu yang ditetapkan oleh peneliti untuk dipelajari dan kemudian ditarik kesimpulannya.

Populasi adalah serumpun atau sekelompok objek yang menjadi sasaran penelitian. Oleh karenanya, populasi penelitian merupakan keseluruhan dari obyek penelitian yang dapat berupa manusia, hewan, gejala, nilai, peristiwa, sikap hidup dan sebagainya, sehingga obyek - obyek ini dapat menjadi sumber data penelitian.

Populasi dalam penelitian ini adalah 38 Pegawai berstatus PNS. Dengan demikian jumlah sampel dalam penelitian sebanyak 38 Pegawai. 


\section{Sampel}

Menurut Manullang dan Pakpahan ( 2014 : 71 ) "sampel adalah wakil-wakil dari populasi. “Sedangkan menurut Sugiyono ( $2010: 118$ " sampel adalah bagian dari jumlah dan karakteristik yang dimiliki oleh populasi tersebut." Dapat disimpulkan bahwa sampel merupakan bagian dari populasi yang mempunyai karakteristik dan sifat yang mewakili seluruh populasi yang ada.

Berdasarkan defenisi diatas maka jumlah sampel dalam penelitian ini seluruh Pegawai Dinas Kebudayaan Kota Medan yang berstatus PNS sebanyak 38 orang.

\section{Sumber Data, Variabel \\ Sumber Data}

Yang dimaksud dengan sumber data dalam penelitian ini adalah "subyek darimana dapat diperoleh". Adapun mengenai sumber data dalam penelitian ini dikelompokkan menjadi :

\section{a. Data Primer}

Data primer adalah data yang diperoleh secara langsung dari sumber data yang diteliti dengan melakukan pengamatan dan pencatatan secara sistematis terhadap masalah yang dihadapi. Dalam penelitian ini contoh data primernya adalah data yang diperoleh melalui angket dan wawancara dengan Pegawai Dinas Kebudayaan Kota Medan

b. Data Sekunder

Data sekunder merupakan data yang mendukung pembahasan dan diperoleh dari orang lain berupa internet, jurnal, dan buku.

\section{Variabel}

Variabel penelitian pada dasarnya adalah sesuatu hal yang berbentuk apa saja yang ditetapkan oleh peneliti untuk dipelajari sehingga diperoleh informasi tentang hal tersebut, kemudian ditarik kesimpulannya.

a. Variabel bebas (Variabel Independen)

Variabel bebas adalah variabel yang mempengaruhi atau yang menjadi sebab perubahannya atau timbulnya variabel dependen (terikat). Dalam penelitian ini yang menjadi variabel bebasnya adalah "Motivasi Kerja " yang diberi simbol X1 dan " Kompetensi kerja " yang diberi simbol X2.

b. Variabel terikat (variabel Dependen)
Variabel terikat adalah variabel yang dipengaruhi atau yang menjadi akibat, karena adanya variabel bebas. Dalam penelitian ini yang menjadi variabel terikatnya adalah "Kinerja Pegawai " yang diberi simbol Y.

\section{Metode Pengumpulan Data, Instrumen Penelitian \\ Metode Pengumpulan Data}

Metode pengumpulan data adalah alat pada waktu penelitian menggunakan suatu metode. Dalam melakukan penelitian pasti ada proses pengumpulan data dengan menggunakan teknik - teknik tertentu yang disesuaikan dengan karakteristik penelitian yang dilakukan. Untuk mengumpulkan data sebanyak mungkin peneliti menggunakan metode pengumpulan data sebagai berikut :

\section{a. Teknik Observasi}

Observasi biasa disebut dengan istilah pengamatan. Teknik observasi atau pengamatan adalah "suatu teknik yang dilakukan dengan cara mengadakan pengamatan secara teliti serta pencatatan secara sistematis". Dalam keterangan lain dikemukakan bahwa observasi adalah "pengamatan dan pencatatan dengan sistematik fenomena - fenomena yang diselidiki”.

\section{b. Metode Kuesioner}

Kuesioner adalah teknik pengumpulan data yang dilakukan dengan cara memberi seperangkat pertanyaan tertulis kepada responden untuk dijawabnya. kuesioner merupakan teknik pengumpulan data yang efisien bila peneliti tahu dengan pasti variabel yang akan diukur dan tahu apa yang bisa diharapkan dari responden. Angket (kuesioner) adalah usaha pengumpulan informasi dengan menyampaikan sejumlah pertanyaan tertulis untuk dijawab secara tertulis oleh responden.

\section{Instrumen Penelitian}

Instrumen Penelitian yang digunakan pada penelitian ini adalah skala model likert yang dibuat oleh peneliti sendiri berdasarkan teori-teori yang terkait dengan variabelvariabel penelitian. Skala model Likert adalah skala yang digunakan untuk mengukur sikap, pendapat, dan persepsi seseorang atau 
sekelompok orang tentang fenomena sosial. Dengan skala likert, maka variabel yang akan diukur menjadi indikator variabel. Kemudian indikator tersebut dijadikan sebagai titik tolak untuk menyusun item-item instrumen yang dapat berupa pernyataan atau pertanyaan. Skala dipilih sebagai instrumen penelitian karena skala dapat dengan mudah mengungkap atribut yang hendak diukur atas jawaban yang telah diberikan oleh responden. Cara pengukuran dengan menghadapkan responden pada sebuah pertanyaan dan kemudian responden diminta untuk memberikan jawaban.

\section{Analisis Data}

\section{Analisis Regresi Linier Berganda}

Analisis regresi ganda bertujuan untuk meramalkan nilai pengaruh dua atau lebih variabel bebas terhadap satu variabel terikat dengan menggunakan persamaan regresi sebagai berikut :

$\mathrm{Y}^{\prime}=\mathrm{a}+\mathrm{b}_{1} \mathrm{X}_{1}+\mathrm{b}_{2} \mathrm{X}_{2}+\mathrm{e}$ Gujarat dalam Ghozali (2006:145)

Keterangan:

$\mathrm{Y}^{\prime}=$ Variabel dependen (nilai yang diprediksikan)

$\mathrm{X}_{1}=$ Variabel Independen

$\mathrm{X}_{2}=$ Variabel independen

$\mathrm{a}=$ Konstanta (nilai $\mathrm{Y}$ apabila $\mathrm{X}_{1}, \mathrm{X}_{2} \ldots \ldots \mathrm{X}_{\mathrm{n}}=$ $0)$

$\mathrm{b}=$ Koefisien regresi (nilai peningkatan ataupun penurunan)

$\mathrm{e}=$ error sampling

\section{Uji Hipotesis}

Pembuktian hipotesis dilakukan dengan menggunakan uji statistik yang didukung oleh uji ekonometrika sebagai berikut :

\section{Uji t (t-test)}

Uji $t$ ini digunakan untuk membuktikan pengaruh yang signifikan antara variabel independen terhadap variabel dependen, dimana apabila nilai t hitung lebih besar dari $t$ tabel menunjukkan diterimanya hipotesis yang diajukan.

Untuk melakukan uji keberartian korelasi variabel Motivasi Kerja dan Kompetensi Kerja secara sendiri-sendiri atau parsial digunakan uji-t.Untuk menguji signifikansi pengaruh, maka perlu diuji signfikansinya dengan rumus uji t (Sugiono, 2005:97) seperti rumus berikut

$$
t=\frac{\mathrm{r} \sqrt{(\mathrm{n}-2)}}{\sqrt{\left(1-\mathrm{r}^{2}\right)}}
$$

Dimana :

$\mathrm{t}$ hitung $=$ nilai $\mathrm{t}$

$\mathrm{r} \quad=$ Nilai koefisien korelasi

$\mathrm{n} \quad=$ Jumlah sampel

Nilai t hitung dapat dilihat pada hasil regresi dan nilai $\mathrm{t}$ tabel didapat melalui sig. $\alpha=$ 0,05 dengan $\mathrm{df}=\mathrm{n}-\mathrm{k}$.

Kriteria :

a. Apabila $\mathrm{t}$ hitung $<\mathrm{t}$ tabel, maka $\mathrm{H} 0$ diterima dan Ha ditolak, artinya tidak ada pengaruh secara parsial.

b. Apabila $\mathrm{t}$ hitung $>\mathrm{t}$ tabel, maka $\mathrm{Ha}$ diterima dan H0 ditolak, artinya ada pengaruh secara parsial.

Nilai $\mathrm{t}$ hitung dapat dilihat pada hasil regresi dan nilai $t$ tabel didapat melalui sig. $\alpha=$ 0,05 dengan $\mathrm{df}=\mathrm{n}-\mathrm{k}$.

\section{Uji F (F -test)}

Untuk menguji keberartian korelasi untuk dua variabel bebas secara bersama-bersama yang dihubungkan dengan variabel terikat digunakan uji F (Sudjana, 2005:385)

$$
F=\frac{\mathrm{R} 2 / \mathrm{K} / \mathrm{K}}{(1-\mathrm{R} 2) /(\mathrm{n}-1-\mathrm{k})}
$$

Dimana :

$\mathrm{R}^{2}=$ koefisien korelasi berganda dikuadratkan

$\mathrm{n}=$ jumlah sampel

$\mathrm{k}=$ jumlah variabel bebas

Uji $F$ digunakan untuk mengetahui apakah regresi yang digunakan cukup baik atau tidak. Uji $\mathrm{F}$ dapat dilihat dari nilai $\mathrm{F}$ hitung dengan kriteria sebagai berikut :

a. Jika $F$ test $\geq$ Ftabel dan nilai signifakansi $<0.05$ maka ada pengaruh antara variabel bebas terhadap variabel terikat, dengan demikian pengujian model tersebut dikatakan baik.

b. Jika $F$ test $\leq$ Ftabel dan nilai signifakansi $>0.05$ maka tidak ada pengaruh antara variabel bebas terhadap variabel terikat. Dengan demikian pengujian model tersebut dikatakan tidak baik. 


\section{HASIL PENELITIAN}

\section{Analisa Korelasi dan Regresi Berganda}

Analisa Regresi Berganda digunakan untuk mengetahui seberapa besar pengaruh variabel bebas terhadap variabel terikat. Berikut persamaan regresinya :

Tabel 1. Regresi Linier Berganda Coefficients $^{\mathrm{a}}$

\begin{tabular}{|c|c|c|c|c|c|}
\hline \multirow[b]{2}{*}{ Model } & \multicolumn{2}{|c|}{$\begin{array}{c}\text { Unstandardiz } \\
\text { ed } \\
\text { Coefficients }\end{array}$} & \multirow{2}{*}{\begin{tabular}{|c|}
$\begin{array}{c}\text { Standardi } \\
\text { zed } \\
\text { Coefficien } \\
\text { ts }\end{array}$ \\
\\
Beta \\
\end{tabular}} & \multirow[b]{2}{*}{$\mathrm{T}$} & \multirow[b]{2}{*}{ Sig. } \\
\hline & B & $\begin{array}{l}\text { Std. } \\
\text { Error }\end{array}$ & & & \\
\hline $\begin{array}{ll}1 & \text { (Consta } \\
\text { nt) }\end{array}$ & .417 & 2.263 & & .718 & .027 \\
\hline $\begin{array}{l}\text { Motivas } \\
\text { i Kerja }\end{array}$ & .071 & .140 & .086 & 3.721 & $.01^{\circ}$ \\
\hline $\begin{array}{l}\text { Kompet } \\
\text { ensi } \\
\text { Kerja }\end{array}$ & .679 & .126 & .683 & 4.073 & .00 \\
\hline
\end{tabular}

a. Dependent Variable: Kinerja Pegawai

Sumber : Hasil Regresi Linier Berganda SPSS Versi 17

Pada tabel diatas menunjukkan bahwa Model Persamaan Regresi Berganda ( $\mathrm{Y}=\mathrm{A}+$ $\left.\mathrm{B}_{1} \mathrm{X}_{1}+\mathrm{B}_{2} \mathrm{X}_{2}+\mathrm{e}\right)$ pada penelitian ini adalah

$$
\mathrm{Y}=0,417+0,071 \mathrm{X}_{1}+0,679 \mathrm{X}_{2} \text {. }
$$

Dari persamaan regresi tersebut didapat bahwa variabel Motivasi Kerja, dan Kompetensi Kerja memiliki koefisien positif. Hal ini berarti bahwa variable Motivasi Kerja, dan Kompetensi Kerja berhubungan positif terhadap Kinerja Pegawai.

\section{Uji Hipotesis}

\section{Uji t (Uji Parsial)}

Uji t pada penelitian ini dilakukan untuk mengetahui apakah terdapat pengaruh yang signifikan dari variabel bebas (X) terhadap variabel terikat (Y).

Uji $\mathrm{t}$ dilakukan dengan hipotesis sebagai berikut :

a. $\mathrm{H}_{0} \quad$ : bi $=0 ; \quad$ (artinya variabel Independen berpengaruh secara parsial terhadap Dependen ). b. $\quad \mathrm{H}_{1} \quad$ : $\mathrm{bi} \neq 0$; (artinya variabel Independen tidak berpengaruh secara parsial terhadap Dependen).

Nilai t-hitung akan dibandingkan dengan ttabel dengan kriteria yaitu:

a. $\quad \mathrm{H}_{0}$ diterima jika $\mathrm{t}$-tabel $\leq \mathrm{t}_{\text {hitung }} \leq \mathrm{t}_{\text {tabel }}$ pada $\alpha=5 \%$

b. $\mathrm{H}_{0}$ ditolak $\left(\mathrm{H}_{1}\right.$ diterima $)$ jika $\mathrm{t}_{\text {-hitung }}<\mathrm{t}$-tabel atau $\mathrm{t}_{\text {-hitung }}>\mathrm{t}_{\text {-tabel }}$ pada $\alpha=5 \%$

$\mathrm{t}_{\text {tabel }}$ diperoleh dengan derajat bebas $=\mathrm{n}-$ $\mathrm{k}$

$\mathrm{n}=$ jumlah sampel yaitu 38 data

$\mathrm{k}=$ jumlah variabel yang digunakan, $\mathrm{k}=$ 3

$\mathrm{n}-\mathrm{k}=38-3=35$

Uji $\mathrm{t}$ yang digunakan adalah uji satu arah dengan $\alpha=5 \%$ maka $t_{\text {tabel }} 5 \%$ (35) adalah 1,68957

Output uji t dapat dilihat pada Tabel dibawah ini :

Tabel 2. Uji -t (Parsial)

Coefficients $^{\mathrm{a}}$

\begin{tabular}{|c|c|c|c|c|c|}
\hline & \multicolumn{2}{|c|}{} & $\begin{array}{c}\text { Standa } \\
\text { rdized } \\
\text { Coeffi } \\
\text { cients }\end{array}$ & & \\
\cline { 2 - 5 } Model & \multicolumn{1}{|c|}{$\begin{array}{c}\text { Unstandardize } \\
\text { d Coefficients }\end{array}$} & $\begin{array}{c}\text { Std. } \\
\text { Error }\end{array}$ & Beta & T & Sig. \\
\cline { 2 - 4 } $\begin{array}{l}\text { (Consta } \\
\text { nt) }\end{array}$ & .417 & 2.263 & & .718 & .027 \\
$\begin{array}{l}\text { Motiva } \\
\text { si Kerja } \\
\text { Kompet } \\
\text { ensi } \\
\text { Kerja }\end{array}$ & .071 & .140 & .086 & 3.721 & .017 \\
\hline
\end{tabular}

a. Dependent Variable: Kinerja Pegawai

Sumber : Hasil Uji t SPSS Versi 17

Pada Tabel diatas menunjukkan bahwa :

1. Nilai $t_{\text {hitung }}$ variabel Motivasi Kerja bernilai 3,721 sedangkan $t_{\text {tabel }}$ bernilai 1,689. Hal ini berarti $t_{\text {hitung }}>t_{\text {tabel }}$ yaitu $3,721>1,677$ dengan nilai signifikan lebih $<0,05$. Berdasarkan data tersebut dapat disimpulkan bahwa variabel Motivasi Kerja secara uji t (uji parsial) bernilai positif yang ditunjukkan dengan hubungan searah dengan variabel kinerja pegawai dan berpengaruh signifikan sehingga $\mathrm{H}_{0}$ ditolak dan $\mathrm{H}_{1}$ diterima 
artinya Motivasi Kerja berpengaruh signifikan terhadap kinerja pegawai.

2. Nilai $t_{\text {hitung }}$ variabel Kompetensi Kerja bernilai 4,073 sedangkan $t_{\text {tabel }}$ bernilai 1,689. Hal ini berarti $t_{\text {hitung }}>t_{\text {tabel }}$ yaitu 4,073> 1,689 dengan nilai signifikan lebih $<0,05$. Berdasarkan data tersebut dapat disimpulkan bahwa variabel Kompetensi Kerja secara uji t (uji parsial) bernilai positif yang ditunjukkan dengan hubungan searah dengan variabel kinerja pegawai dan berpengaruh signifikan sehingga $\mathrm{H}_{0}$ ditolak dan $\mathrm{H}_{1}$ diterima artinya Kompetensi Kerja berpengaruh signifikan terhadap kinerja pegawai.

\section{Uji F (Uji Simultan)}

Uji F dilakukan untuk mengetahui apakah variabel-variabel bebas Motivasi Kerja dan Kompetensi Kerja $\left(\mathrm{X}_{1}\right.$ dan $\left.\mathrm{X}_{2}\right)$ secara bersama-sama memiliki pengaruh yang signifikan terhadap variabel terikat $(\mathrm{Y})$ yaitu kinerja pegawai . Model hipotesis ini adalah : $\mathrm{H}_{0}: \mathrm{b}_{1}, \mathrm{~b}_{2}=0$ (artinya variabel Motivasi Kerja dan Kompetensi Kerja secara simultan berpengaruh terhadap kinerja pegawai).

$\mathrm{H}_{1}: \mathrm{b}_{1}, \mathrm{~b}_{2}, \neq 0$ (artinya variabel Motivasi Kerja dan Kompetensi Kerja secara simultan tidak berpengaruh terhadap Kinerja Pegawai).

Alat uji yang digunakan untuk menerima atau menolak hipotesis, yaitu nilai $\mathrm{F}_{\text {-hitung }}$ dibandingkan dengan nilai $\mathrm{F}_{\text {tabel }}$ dengan kriteria yaitu :

a. $\mathrm{H}_{0}$ diterima jika $\mathrm{F}_{\text {-hitung }}<\mathrm{F}_{\text {tabel }}$ pada $\alpha=$ $5 \%$

b. $\mathrm{H}_{0}$ ditolak $\left(\mathrm{H}_{1}\right.$ diterima) jika $\mathrm{F}_{\text {-hitung }}>\mathrm{F}-$ tabel pada $\alpha=5 \%$

$\mathrm{F}$ tabel diperoleh dengan derajat bebas $(\mathrm{df} 1=\mathrm{k}-1)$

$\mathrm{n}=$ jumlah sampel yaitu 51 data

$\mathrm{k}=$ jumlah variabel yang digunakan, $\mathrm{k}=$ 3

df $1=\mathrm{k}-1=3-1=2$

df $2=\mathrm{n}-\mathrm{k}=38-3=35$

Uji $\mathrm{F}$ yang digunakan adalah uji satu arah dengan $\alpha=5 \%$ maka $\mathrm{F}_{\text {tabel }} 5 \%(2 ; 35)$ adalah 3,27. Output uji $\mathrm{F}$ dapat dilihat pada Tabel dibawah ini :
Tabel 3. Uji F

ANOVA $^{\text {b }}$
\begin{tabular}{|l|c|r|c|c|c|}
\hline Model & $\begin{array}{c}\text { Sum of } \\
\text { Squares }\end{array}$ & df & $\begin{array}{c}\text { Mean } \\
\text { Square }\end{array}$ & F & Sig. \\
\hline $1 \quad$ Regressi & 1213.672 & 2 & 545.284 & 62.327 & $.000^{\mathrm{a}}$ \\
on & & & & & \\
Residual & 21.366 & 35 & .716 & & \\
Total & 535.038 & 37 & & & \\
\hline
\end{tabular}

a. Predictors: (Constant), Kompetensi Kerja, Motivasi Kerja

b. Dependent Variable: Kinerja Pegawai Sumber : Hasil Uji F SPSS

Pada Tabel menunjukkan bahwa nilai $F_{\text {hitung }}$ variabel Motivasi Kerja dan Kompetensi Kerja bernilai 62,327 sedangkan $F_{\text {tabel }}$ bernilai 3,27. Hal ini berarti $F_{\text {hitung }}>F_{\text {tabel }}$ yaitu 62,327 $>$ 3,37. Berdasarkan data tersebut dapat disimpulkan bahwa variabel Motivasi Kerja dan Kompetensi Kerja secara uji F (uji simultan) bernilai positif yang ditunjukkan dengan hubungan searah dengan variabel Kinerja Pegawai dan berpengaruh signifikan, sehingga $\mathrm{H}_{0}$ ditolak dan $\mathrm{H}_{1}$ diterima.

\section{Pembahasan Hasil Penelitian}

Dari hasil uji SPSS 20 diperoleh hasil penelitian sebagai berikut. (1) Motivasi Kerja memiliki hubungan positf dan signifikan terhadap Kinerja Pegawai Dinas Kebudayaan Kota Medan . Hasil penelitian ini sejalan dengan penelitian sebelumnya yang dilakukan oleh Safwan (2014), Gusti Ayu (2012), dimana Motivasi Kerja berpengaruh positif dan signifikan terhadap Kinerja Karyawan. (2) Kompetensi Kerja memiliki hubungan positif dan signifikan terhadap Kinerja Pegawai Dinas Kebudayaan Kota Medan. Hasil penelitian ini berbeda dengan hasil penelitian yang dilakukan oleh Linawati Suhaji (2012) yang menemukan secara parsial Kompetensi tidak berpengaruh signifikan dan berbanding terbalik terhadap Kinerja Karyawan PT. Herculon Carpet Semarang. Tetapi secara sumultan Kompetensi Kerja, dan Motivasi Kerja berpengaruh positif terhadap Kinerja Karyawan. Dengan adanya hasil penelitian ini yang menghasilkan bahwa Motivasi Kerja, dan Kompetensi Kerja berpengaruh secara simultan terhadap Kinerja Pegawai. Pengaruh simultan dari variable-variabel independen 
tersebut terhadap Kinerja Pegawai mencapai angka $72.3 \%$, sisanya 27,7 dipengaruhi factor lain. Dengan demikian variable-variabel tersebut dapat menjadi acuan bagi manajemen Dinas Kebudayaan Kota Medan dalam melakukan peningkatkan kinerja pegawai.

\section{Kesimpulan}

1. Motivasi kerja yang tinggi dapat meningkatkan Kinerja Pegawai

2. Kompetensi Kerja yang tinggi dapat meningkatkan Kinerja Pegawai

3. Motivasi Kerja dan Kompetensi Kerja Variabel Motivasi Kerja dan Kompetensi Kerja berpengaruh signifikan terhadap Kinerja Pegawai (Y).

\section{Saran}

Sebagai bahan pertimbangan bagi pihak perusahaan yang berdasarkan hasil analisis dan kesimpulan diatas, maka disarankan agar:

1. Pimpinan melakukan analisa terhadap tiap Pegawai dan mengenali faktor-faktor yang dapat meningkatkan motivasi kerja pegawai dan memberikan penghargaan kepada karyawan yang berprestasi baik berupa promosi jabatan, hadiah dan lain-lain.

2. Untuk meningkatkan kompetensi kerja pegawai Dinas Kebudayaan Kota Medan dapat memberikan pendidikan dan pelatihan yang berhubungan dengan masalah kepribadian, penguasaan diri, motivasi kerja sehingga pegawai lebih semangat dan percaya diri dalam bekerja.

\section{DAFTAR PUSTAKA}

Gouzali Saydam, 2005. Manajemen Sumber Daya Manusia: Suatu Pendekatan Mikro, Jakarta : Djambaran. 2010, Manajemen Sumber Daya Manusia, Jakarta : Binarupa.

Mangkunegara, Anwar prabu, 2005, Manajemen Sumber Daya, Bandung : Penerbit PT. Remaja Rosdakarya,

Mangkunegara, Anwar prabu, 2014, Manajemen Sumber Daya Manusia Perusahan, Bandung : Penerbit PT. Remaja Rosdakarya,
,2011. Manajemen Sumber

Daya Manusia Perusahaan. Bandung: Rosada

Manullang, 2013, Dasar-Dasar Manajemen, Bandung : Ciptapustaka Media Perintis.

Manullang, Marihot \& Pakpahan, Manuntun. 2014 Metodologi Penelitian: Proses Penelitian Praktis. Ciptapustaka Media: Bandung

Moekijat.2012. Latihan dan Pengembangan Sumber Daya Manusia . Bandung: Bandar Maju

Priansa, Donni Joni.2014. Perencanaan dan Pengembangan Sumber Daya Manusia. Bandung: Alfabeta.

Sugiyono,. 2010. Metode Penelitian Pendidikan: Pendekatan Kuantitatif, Kualitatif, dan $R \& D$. Bandung : Penerbit Alfabeta

Tjuttju Yuniarsih \&Suwatno, 2008 Manajemen Sumber Daya Manusia Teori Aplikasi dan Isu Penelitian, Bandung: CV. Alfabeta..

Uno Hamzah B. 2009. Model Pembelajaran Menciptakan proses Belajar Mengajar yang Kreatif Efektif . Jakarta : Bumi Aksara

Wibowo, 2007, Manajemen Kinerja Edisi Kedua Jakarta: PT. Raja Grafindo Persada

Wursanto, IC, (2005), Dasar-Dasar Manajemen Personalia, Jakarta : Pustaka Dian. 